\title{
Productivity of Groundnut + Pigeonpea Relay Intercropping System as Influenced by Weed Management Options
}

Varsha Nakala, R.K. Mathukia, P.K. Chovatia, R.M. Solanki

10.18805/LR-4754

\begin{abstract}
Background: Weed management is one of the most important agronomic constraints leading to severe losses in the cropping system. Intercropping has several advantages to mitigate the losses faced by monocropping in addition to which if there is a proper control of weeds then the advantages of the intercropping system can be multiplied.

Methods: An investigation was conducted on medium black clayey soils at Junagadh during kharif 2019-20 and 2020-21 in randomized block design with 10 treatments replicated thrice, to evaluate the effect of different weed management options on the growth and yield of groundnut + pigeonpea relay intercropping. The treatments were: pendimethalin $0.9 \mathrm{~kg} \mathrm{ha}^{-1}$ as PE $\mathrm{fb}$ interculture and hand weeding at 45 DAS $\left(T_{1}\right)$, pendimethalin $0.45 \mathrm{~kg} \mathrm{ha}^{-1}+$ oxyfluorfen $0.09 \mathrm{~kg} \mathrm{ha}^{-1}$ as PE fb interculture and hand weeding at 45 DAS $\left(T_{2}\right)$, interculture and hand weeding at 15 DAS $f b$ sodium acifluorfen $16.5 \%+$ clodinafop propargyl $8 \%$ (ready mix) $1 \mathrm{~kg} \mathrm{ha}^{-1}$ at 45 DAS as POE ( $\mathrm{T}_{3}$ ), interculture and hand weeding at 15 DAS $f b$ quizalofop $p$ ethyl $40 \mathrm{~g} \mathrm{ha}^{-1}$ at 45 DAS as POE $\left(\mathrm{T}_{4}\right)$, interculture and hand weeding at 15 DAS $\mathrm{fb}$ propaquizafop $70 \mathrm{~g} \mathrm{ha}^{-1}$ at 45 DAS as POE $\left(\mathrm{T}_{5}\right)$, pendimethalin $0.9 \mathrm{~kg} \mathrm{ha}^{-1}$ as PE $\mathrm{fb}$ sodium acifluorfen $16.5 \%$ + clodinafop propargyl $8 \%$ (ready mix) $1 \mathrm{~kg} \mathrm{ha}^{-1}$ at 45 DAS as POE $\left(\mathrm{T}_{6}\right)$, pendimethalin $0.9 \mathrm{~kg} \mathrm{ha}^{-1}$ as aPE fb quizalofop $\mathrm{p}$ ethyl $40 \mathrm{~g} \mathrm{ha}^{-1}$ at 45 DAS as POE ( $\left.\mathrm{T}_{7}\right)$, pendimethalin $0.9 \mathrm{~kg}$ as ha-1 PE $f b$ propaquizafop $70 \mathrm{~g} \mathrm{ha}^{-1}$ at 45 DAS as POE $\left(T_{8}\right)$, weed free $\left(T_{9}\right)$ and unweeded control $\left(T_{10}\right)$.

Result: The results of the experiment revealed that weed free registered significantly higher plant height, number of branches, dry matter per plant and number of root nodules per plant in groundnut and pigeonpea and was statistically on par with to intercultureand hand weeding at 15 DAS fb sodium acifluorfen $16.5 \%$ + clodinafop propargyl $8 \%$ (ready mix) $1 \mathrm{~kg} \mathrm{ha}^{-1}$ at $45 \mathrm{DAS}$ as PoE, pendimethalin $0.9 \mathrm{~kg} \mathrm{ha}^{-1}$ as PE fb sodium acifluorfen $16.5 \%$ + clodinafop propargyl $8 \%$ (ready mix) $1 \mathrm{~kg} \mathrm{ha}^{-1}$ at 45 DAS as PoE. The data on yield attributes and yield of both the crops depicted that significantly superior results were obtained with weed free treatment, which was statistically at par with intercultureand hand weeding at 15 DAS fb sodium acifluorfen $16.5 \%$ + clodinafop propargyl $8 \%$ (Ready mix) $1 \mathrm{~kg} \mathrm{ha}^{-1}$ at 45 DAS as PoE and pendimethalin $0.9 \mathrm{~kg} \mathrm{ha}^{-1}$ as PE fb sodium acifluorfen $16.5 \%$ + clodinafop propargyl $8 \%$ (Ready mix) $1 \mathrm{~kg} \mathrm{ha}^{-1}$ at 45 DAS as PoE. While in case of groundnut equivalent pod and haulm yields, statistically superior yields were registered with weed free treatment, which was statistically at par with intercultureand hand weeding at 15 DAS $f b$ sodium acifluorfen $16.5 \%+$ clodinafop propargyl $8 \%$ (Ready mix) $1 \mathrm{~kg} \mathrm{ha}^{-1}$ at 45 DAS as PoE.
\end{abstract}

Key words: Clodinafop-propargyl, Hand weeding (HW), Interculture (IC), Oxyfluorfen, Pendimethalin, Propaquizafop, Quizalofop-p-ethyl, Sodium-acifluorfen.

\section{INTRODUCTION}

The most feasible approach to enhance crop yield is sowing and growing crops from beginning of monsoon season to post-monsoon season by adopting concept of relay intercropping system (AICRP, 2002-07). Groundnut contributes about 40 per cent to the total oilseeds production in the country (Sathyapriya et al., 2013). It is a leguminous crop, which fixes atmospheric nitrogen and covers the soil. While on the other hand, pigeonpea is a fast-growing crop with its extensive root system. Its deep tap root system allows optimum utilization of soil moisture and soil nutrients and can be an ideal crop in groundnut relay intercropping system and both the crops complement each other. Pigeonpea is used as a most preferred pulse crop by Indian rural and urban communities. Groundnut + pigeonpea is dominant cropping system, which helps to maintain the sustainability and profitability which form the major goals in the present world. Pigeonpea was sown a month after the groundnut crop was sown to reduce the competition between the crops and this may help increase of the yield. This practise is advocated and encouraged by the Pulses Research Station,
Department of Agronomy, Junagadh Agricultural University, Junagadh-362 001, Gujarat, India.

Corresponding Author: Varsha Nakala, Department of Agronomy, Junagadh Agricultural University, Junagadh-362 001, Gujarat, India. Email: nvarsha68.vn@gmail.com

How to cite this article: Nakala, V., Mathukia, R.K., Chovatia, P.K. and Solanki, R.M. (2022). Productivity of Groundnut + Pigeonpea Relay Intercropping System as Influenced by Weed Management Options. Legume Research. DOI: 10.18805/LR-4754. Submitted: 30-07-2021 Accepted: 09-12-2021 Online: 23-02-2022

JAU, Junagadh because of the erratic and scanty rainfall recived in the Saurashtra region making groundnut cultivation risky.

Weed management is an important agronomic aspect in crop production, as weed cause the highest percentage of damage to the crop and especially in dry regions where they compete with the crops for water, nutrients, $\mathrm{CO}_{2}$ and light, ultimately reducing the crop yields to tune of $31 \%$ - 
$59 \%$ (Singh et al., 2020). The traditional practices of weed management i.e., manual weeding is difficult to adopt in the present scenario with the growing labour scarcity and increasing labour wages. Mechanical weeding is difficult in intercropping as the intercrops may be damaged. Hence to reduce the risk and cost, chemical practices can be adopted along with the traditional practice of manual hand weeding. Thus, the crop may be put to advantage supressing the growth of weeds. This not only increases the yield but also reduces the cost of cultivation by decreasing the cost on additional labour utilised for manual weeding. The energy required for the crop production can also be reduced with the appropriate use of weed management practices. Finally, the productivity per unit land can be increased which increases the national income and accelerates the development of the nation. Thus, the proposal of doubling the farmers' income can be made true in a sustainable manner through crop intensification and diversification approach. Groundnut + pigeonpea relay intercropping system is the dominant intercropping system in Saurashtra region of Gujarat. But not much work has been done in the weed management aspect of groundnut + pigeonpea cropping system and especially in the relay intercropping of these crops.

\section{MATERIALS AND METHODS}

A field experiment was conducted at Instructional Farm, Department of Agronomy, College of Agriculture, Junagadh Agricultural University, Junagadh (Gujarat) during kharif seasons of year 2019-20 and 2020-21. The soil of the experimental plot was clayey in texture, medium in organic carbon $(0.62 \%)$, slightly alkaline in reaction with $\mathrm{pH}(8.32)$ and EC $\left(0.286 \mathrm{dS} \mathrm{m}^{-1}\right)$. The soil was low in available nitrogen $\left(270.20 \mathrm{~kg} \mathrm{ha}^{-1}\right)$, medium in available phosphorus $(28.2 \mathrm{~kg}$ $\left.\mathrm{ha}^{-1}\right)$ and medium in available potash $\left(251.7 \mathrm{~kg} \mathrm{ha}^{-1}\right)$.

Additive series of intercropping in 2:1 ratio was adopted, wherein the main/base crop is groundnut and intercrop is pigeonpea. "GG 20" was groundnut variety used for this study as base crop, pigeonpea variety "GJP-1" as intercrop. The experiment was laid out in RBD with ten treatments, which were replicated thrice. The treatments comprised pendimethalin $0.9 \mathrm{~kg} \mathrm{ha}^{-1}$ as PE fb $\mathrm{IC}+\mathrm{HW}$ at $45 \mathrm{DAS}\left(\mathrm{T}_{1}\right)$, pendimethalin $0.45 \mathrm{~kg} \mathrm{ha}^{-1}+$ oxyfluorfen $0.09 \mathrm{~kg} \mathrm{ha}^{-1}$ as $\mathrm{PE}$ $\mathrm{fb} \mathrm{IC}+\mathrm{HW}$ at $45 \mathrm{DAS}\left(\mathrm{T}_{2}\right), \mathrm{IC}+\mathrm{HW}$ at $15 \mathrm{DAS} \mathrm{fb}$ sodiumacifluorfen $16.5 \%$ + clodinafop-propargyl $8 \%$ (Premix) $1 \mathrm{~kg}$ $\mathrm{ha}^{-1}$ at 45 DAS as POE $\left(\mathrm{T}_{3}\right)$, IC+HW at 15 DAS fb quizalofopp-ethyl $40 \mathrm{~g} \mathrm{ha}^{-1}$ at $45 \mathrm{DAS}$ as POE $\left(\mathrm{T}_{4}\right), \mathrm{IC}+\mathrm{HW}$ at $15 \mathrm{DAS}$ fb propaquizafop $70 \mathrm{~g} \mathrm{ha}^{-1}$ at 45 DAS as POE $\left(\mathrm{T}_{5}\right)$, pendimethalin $0.9 \mathrm{~kg} \mathrm{ha}^{-1}$ as $\mathrm{PE}$ fb sodium-acifluorfen $16.5 \%$ + clodinafop-propargyl $8 \%$ (Premix) $1 \mathrm{~kg} \mathrm{ha}^{-1}$ at 45 DAS as $\operatorname{POE}\left(\mathrm{T}_{6}\right)$, pendimethalin $0.9 \mathrm{~kg} \mathrm{ha}^{-1}$ as PE $f b$ quizalofop-pethyl $40 \mathrm{~g} \mathrm{ha}^{-1}$ at 45 DAS as POE $\left(\mathrm{T}_{7}\right)$, pendimethalin $0.9 \mathrm{~kg}$ $\mathrm{ha}^{-1}$ as PE fb propaquizafop $70 \mathrm{~g} \mathrm{ha}^{-1}$ at $45 \mathrm{DAS}$ as POE $\left(T_{8}\right)$, weed free $\left(T_{9}\right)$ and unweeded control $\left(T_{10}\right)$. The practices were adopted in accordance to the proposed treatments. Interculture in combination with hand weeding was carried in treatments 3,4 and 5 at 15 DAS while in treatment 1 and 2 it was conducted at 45 DAS of groundnut. Pre emergence herbicide viz., pendimethalin $30 \%$ EC and oxyfluorfen $23.5 \%$ EC was applied on the next day of sowing of groundnut and post emergence herbicides, quizalofopp-ethyl, propaquizafop and sodium-acifluorfen + clodinafoppropargyl were applied at 45 DAS after intercultivation. The weed free was maintained clean with regular intercultivation and manual weeding. The unweeded control was left unweeding allowing the continuous growth of weeds. The spacing adopted was $60 \mathrm{~cm} \times 10 \mathrm{~cm}$ for groundnut and 120 $\mathrm{cm} \times 20 \mathrm{~cm}$ for pigeonpea to accomadate the row ratio of $2: 1$ and groundnut variety is semi spreading. The growth and yield attributes were recorded at harvest.

\section{RESULTS AND DISCUSSION}

\section{Groundnut}

\section{Plant height}

The weed free treatment $\left(T_{9}\right)$ was found to be significantly superior in plant height $(53.33,54.57$ and $53.95 \mathrm{~cm}$ in 2019$20,2020-21$ and pooled results, respectively) at harvest, which was statistically on par with treatments comprising IC+HW at 15 DAS fb sodium-acifluorfen $16.5 \%$ + clodinafoppropargyl $8 \%$ (Premix) $1 \mathrm{~kg} \mathrm{ha}^{-1}$ at $45 \mathrm{DAS}$ as PoE $\left(\mathrm{T}_{3}\right)$ and pendimethalin $0.9 \mathrm{~kg} \mathrm{ha}^{-1}$ as PE fb sodium-acifluorfen $16.5 \%$ + clodinafop-propargyl $8 \%$ (Premix) $1 \mathrm{~kg} \mathrm{ha}^{-1}$ at 45 DAS as PoE $\left(T_{6}\right)$ in the year 2019-20, 2020-21 and pooled results. On the contrary, the unweeded control $\left(T_{10}\right)$ recorded significantly the lowest plant height $(36.63 \mathrm{~cm}, 39.70 \mathrm{~cm}$ and $38.17 \mathrm{~cm}$ in 2019-20, 2020-21 and pooled results, respectively) (Table 1$)$.

\section{Dry matter per plant}

The weed free treatment $\left(T_{9}\right)$ was noticed to be statistically superior in dry matter per plant at harvest $(31.5,30.1$ and $30.8 \mathrm{~g}$ in 2019-20, 2020-21 and pooled results, respectively), which was on par with IC+HW at 15 DAS fb sodiumacifluorfen $16.5 \%$ + clodinafop-propargyl $8 \%$ (Premix) $1 \mathrm{~kg}$ $\mathrm{ha}^{-1}$ at 45 DAS as PoE $\left(\mathrm{T}_{3}\right)$ and pendimethalin $0.9 \mathrm{~kg} \mathrm{ha}^{-1}$ as PE fb sodium-acifluorfen $16.5 \%$ + clodinafop-propargyl $8 \%$ (Premix) $1 \mathrm{~kg} \mathrm{ha}^{-1}$ at 45 DAS as PoE $\left(\mathrm{T}_{6}\right)$ in 2019-20 and pooled results. In the second year, the weed free treatment $\left(T_{9}\right)$ was found to be at par with treatments $\mathrm{T}_{3}(\mathrm{IC}+\mathrm{HW}$ at 15 DAS fb sodium-acifluorfen $16.5 \%$ + clodinafop-propargyl $8 \%$ (Premix) $1 \mathrm{~kg} \mathrm{ha}^{-1}$ at 45 DAS as PoE), $\mathrm{T}_{6}$ (Pendimethalin 0.9 $\mathrm{kg} \mathrm{ha}^{-1}$ as PE $\mathrm{fb}$ sodium-acifluorfen $16.5 \%$ + clodinafoppropargyl $8 \%$ (Premix) $1 \mathrm{~kg} \mathrm{ha}^{-1}$ at 45 DAS as PoE), $\mathrm{T}_{1}$ (Pendimethalin $0.9 \mathrm{~kg} \mathrm{ha}^{-1} \mathrm{PE}$ fb IC+HW at 45 DAS) and $\mathrm{T}_{2}$ (Pendimethalin $0.45 \mathrm{~kg} \mathrm{ha}^{-1}+$ oxyfluorfen $0.09 \mathrm{~kg} \mathrm{ha}^{-1} \mathrm{PE} \mathrm{fb}$ $\mathrm{IC}+\mathrm{HW}$ at $45 \mathrm{DAS})$. The unweeded control $\left(\mathrm{T}_{10}\right)$ recorded significantly the lowest dry matter per plant (17.2, 15.5 and $16.3 \mathrm{~g}$ ) in 2019-20, 2020-21 and pooled results (Table 1).

\section{Pigeonpea}

\section{Plant height}

At harvest, significantly taller plants $(202.4,191.4$ and 196.9 $\mathrm{cm}$ in 2019-20, 2020-21 and pooled results, respectively) 


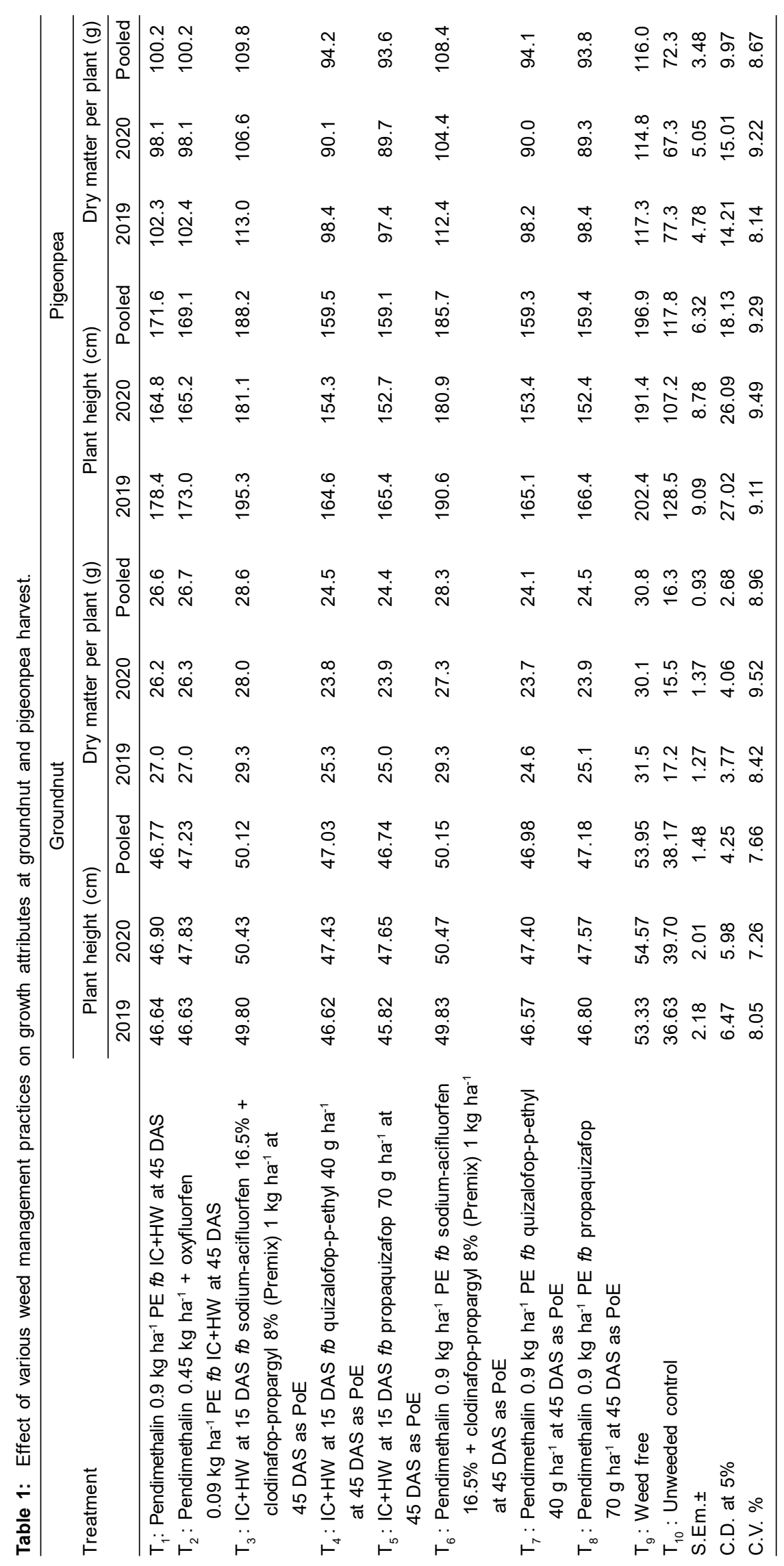


Productivity of Groundnut + Pigeonpea Relay Intercropping System as Influenced by Weed Management Options

were recorded with the weed free treatment $\left(T_{9}\right)$ in both 2019-20, 2020-21 and pooled results and was statistically on par with IC+HW at 15 DAS fb sodium-acifluorfen $16.5 \%$ + clodinafop-propargyl $8 \%$ (Premix) $1 \mathrm{~kg} \mathrm{ha}^{-1}$ at 45 DAS as PoE $\left(\mathrm{T}_{3}\right)$, pendimethalin $0.9 \mathrm{~kg} \mathrm{ha}^{-1}$ as PE $\mathrm{fb}$ sodiumacifluorfen $16.5 \%$ + clodinafop-propargyl $8 \%$ (Premix) $1 \mathrm{~kg}$ $\mathrm{ha}^{-1}$ at 45 DAS as PoE ( $\left.\mathrm{T}_{6}\right)$ during the year 2019-20. Treatment $\mathrm{T}_{9}$ (Weed free) was noticed to be statistically at par with $T_{3}$ and $T_{6}$ during 2020-21 and pooled results (Table 1$)$. The unweeded control $\left(T_{10}\right)$ recorded significantly the lowest plant height $(128.5,107.2$ and $117.8 \mathrm{~cm}$ in 2019$20,2020-21$ and pooled results, respectively) in both years as well as pooled results.

\section{Dry matter per plant}

At harvest, the weed free treatment $\left(T_{9}\right)$ recorded significantly greater crop dry matter per plant $(64.5,60.9$ and $62.7 \mathrm{~g}$ in 2019-20, 2020-21 and pooled results, respectively) and was at par with $\mathrm{IC}+\mathrm{HW}$ at $15 \mathrm{DAS}$ fb sodium-acifluorfen $16.5 \%$ + clodinafop-propargyl $8 \%$ (Premix) $1 \mathrm{~kg} \mathrm{ha}^{-1}$ at 45 DAS as $\operatorname{PoE}\left(\mathrm{T}_{3}\right)$ and pendimethalin $0.9 \mathrm{~kg} \mathrm{ha}^{-1}$ as PE fb sodiumacifluorfen $16.5 \%$ + clodinafop-propargyl $8 \%$ (Premix) $1 \mathrm{~kg}$ $\mathrm{ha}^{-1}$ at 45 DAS as PoE $\left(\mathrm{T}_{6}\right)$ during 2019-20, 2020-21 and pooled results. In 2019-20 and 2020-21, treatments $T_{3}$ $(\mathrm{IC}+\mathrm{HW}$ at 15 DAS fb sodium-acifluorfen $16.5 \%+$ clodinafop-propargyl $8 \%$ (Premix) $1 \mathrm{~kg} \mathrm{ha}^{-1}$ at 45 DAS as $\mathrm{PoE}$ ) and $\mathrm{T}_{6}$ (Pendimethalin $0.9 \mathrm{~kg} \mathrm{ha}^{-1}$ as PE $\mathrm{fb}$ sodiumacifluorfen $16.5 \%$ + clodinafop-propargyl $8 \%$ (Premix) $1 \mathrm{~kg}$ $\mathrm{ha}^{-1}$ at 45 DAS as PoE) were found to be at par with pendimethalin $0.9 \mathrm{~kg} \mathrm{ha}^{-1}$ as PE $\mathrm{fb} \mathrm{IC}+\mathrm{HW}$ at $45 \mathrm{DAS}\left(\mathrm{T}_{1}\right)$ and pendimethalin $0.45 \mathrm{~kg} \mathrm{ha}^{-1}+$ oxyfluorfen $0.09 \mathrm{~kg} \mathrm{ha}^{-1}$ as PE $\mathrm{fb} \mathrm{IC}+\mathrm{HW}$ at $45 \mathrm{DAS}\left(\mathrm{T}_{2}\right)$. Significantly lower crop dry matter per plant $(35.5,32.4$ and $34.0 \mathrm{~g}$ in 2019-20, 2020-21 and pooled results, respectively) was recorded with the unweeded control $\left(T_{10}\right)$ during both years and pooled data (Table 1).

\section{Groundnut}

\section{Number of mature and immature pods per plant}

The data on number of mature and immature pods per plant in groundnut are furnished in Table 2.

\section{Number of mature pods}

Significantly more number of mature pods per plant (11.86, 10.98 and 11.42 in 2019-20, 2020-21 and pooled results, respectively) was recorded with the weed free treatment $\left(T_{9}\right)$ and it was at par with $\mathrm{IC}+\mathrm{HW}$ at 15 DAS $f b$ sodiumacifluorfen $16.5 \%$ + clodinafop-propargyl $8 \%$ (Premix) $1 \mathrm{~kg}$ $\mathrm{ha}^{-1}$ at 45 DAS as PoE $\left(\mathrm{T}_{3}\right)$ and pendimethalin $0.9 \mathrm{~kg} \mathrm{ha}^{-1}$ as $\mathrm{PE}$ fb sodium-acifluorfen $16.5 \%$ + clodinafop-propargyl $8 \%$ (Premix) $1 \mathrm{~kg} \mathrm{ha}^{-1}$ at $45 \mathrm{DAS}$ as $\operatorname{PoE}\left(\mathrm{T}_{6}\right)$ during both the years along with pooled results. However, treatments $T_{3}$ and $\mathrm{T}_{6}$ were statistically on par with pendimethalin $0.9 \mathrm{~kg} \mathrm{ha}^{-1}$ $\mathrm{PE}$ fb IC+HW at $45 \mathrm{DAS}\left(\mathrm{T}_{1}\right)$ and pendimethalin $0.45 \mathrm{~kg} \mathrm{ha}^{-1}+$ oxyfluorfen $0.09 \mathrm{~kg} \mathrm{ha}^{-1}$ as PE $\mathrm{fb} \mathrm{IC}+\mathrm{HW}$ at $45 \mathrm{DAS}\left(\mathrm{T}_{2}\right)$ during 2019-20 and 2020-21. Significantly lesser number of mature pods (6.29, 5.78 and 6.04 in 2019-20, 2020-21 and pooled results, respectively) was observed with the unweeded control $\left(T_{10}\right)$ due to the heavy weed competition.

\section{Pod yield}

Significantly higher pod yield (1956, 1735 and $1846 \mathrm{~kg} \mathrm{ha}^{-1}$ in 2019-20, 2020-21 and pooled results, respectively) was acquired by the weed free treatment $\left(T_{9}\right)$, which was statistically on par with treatments viz., IC+HW at 15 DAS fb sodium-acifluorfen $16.5 \%$ + clodinafop-propargyl $8 \%$ (Premix) $1 \mathrm{~kg} \mathrm{ha}^{-1}$ at $45 \mathrm{DAS}$ as $\operatorname{PoE}\left(\mathrm{T}_{3}\right)$ and pendimethalin $0.9 \mathrm{~kg} \mathrm{ha}^{-1} \mathrm{PE}$ fb sodium-acifluorfen $16.5 \%$ + clodinafoppropargyl $8 \%$ (Premix) $1 \mathrm{~kg} \mathrm{ha}^{-1}$ at $45 \mathrm{DAS}$ as PoE $\left(\mathrm{T}_{6}\right)$ in the year 2019-20, while in the second year and pooled data, the weed free treatment $\left(T_{9}\right)$ was found to statistically at par with only $T_{3}$. However, $T_{3}$ was on par with $T_{6}, T_{1}, T_{2}$ during both the years as well as the pooled data. Conversely, the unweeded control $\left(\mathrm{T}_{10}\right)$ recorded significantly the lowest pod yield $\left(585,436\right.$ and $510 \mathrm{~kg} \mathrm{ha}^{-1}$ in 2019-20, 2020-21 and pooled results, respectively).

\section{Haulm yield}

In the both the years (2019-20 and 2020-21) and pooled data, the weed free treatment $\left(T_{9}\right)$ registered significantly higher groundnut haulm yield $\left(3593,2950\right.$ and $3271 \mathrm{~kg} \mathrm{ha}^{-1}$ in 2019-20, 2020-21 and pooled results, respectively). The weed free treatment $\left(T_{9}\right)$ was at par with $\mathrm{IC}+\mathrm{HW}$ at $15 \mathrm{DAS}$ fb sodium-acifluorfen $16.5 \%$ + clodinafop-propargyl $8 \%$ (Premix) $1 \mathrm{~kg} \mathrm{ha}^{-1}$ at $45 \mathrm{DAS}$ as $\operatorname{PoE}\left(\mathrm{T}_{3}\right)$, pendimethalin 0.9 $\mathrm{kg} \mathrm{ha}^{-1}$ as PE $f b$ sodium-acifluorfen $16.5 \%$ + clodinafoppropargyl $8 \%$ (Premix) $1 \mathrm{~kg} \mathrm{ha}^{-1}$ at $45 \mathrm{DAS}$ as PoE $\left(\mathrm{T}_{6}\right)$ during 2019-20, 2020-21 and pooled results and in turn the treatment $\mathrm{T}_{3}$ was at par with $\mathrm{T}_{2}$ (Pendimethalin $0.45 \mathrm{~kg} \mathrm{ha}^{-1}+$ oxyfluorfen $0.09 \mathrm{~kg} \mathrm{ha}^{-1}$ as PE $\mathrm{fb} \mathrm{IC}+\mathrm{HW}$ at $45 \mathrm{DAS}$ ) and $\mathrm{T}_{1}$ (Pendimethalin $0.9 \mathrm{~kg} \mathrm{ha}^{-1}$ as PE $\mathrm{fb} \mathrm{IC}+\mathrm{HW}$ at $45 \mathrm{DAS}$ ). The unweeded control $\left(T_{10}\right)$ recorded significantly the lowest haulm yield (1150, 823 and $987 \mathrm{~kg} \mathrm{ha}^{-1}$ in 2019-20, 2020-21 and pooled results, respectively).

The effect of rainfall faded at the end of cropping season and clear-cut difference among the treatments was noticed in yield attributes and yield. The superior values in number of mature pods per plant, pod yield, haulm yield and lower values of number of immature pods per plant were registered with the weed free treatment, which was statistically at par with treatments $T_{3}$ and $T_{6}$. The zero competition from weeds under the weed free conditions might have resulted in the luxurious growth of the groundnut crop. The higher values of yield and yield attributes under herbicidal treatments could be attributed to increase in growth characters like plant height and dry matter per plant due to proper integration of weed management practices, which resulted in lower dry weight of weeds which is negatively correlated to the yield ultimately reducing the weed competition favouring the crop growth and productivity. The better plant growth and improved yield attributes finally led to higher dry pod, kernel and haulm yields. The effective weed control in critical crop 


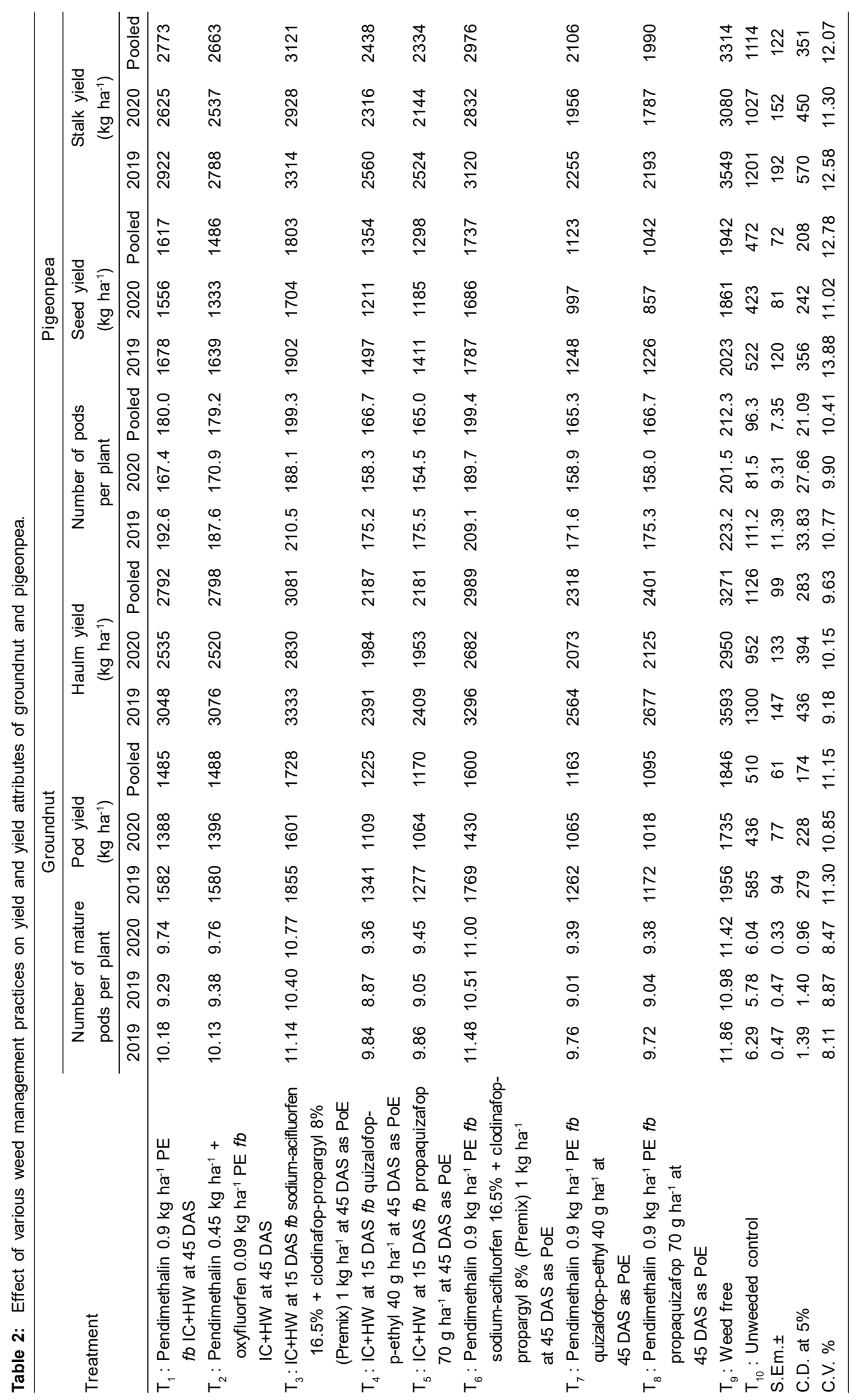


Productivity of Groundnut + Pigeonpea Relay Intercropping System as Influenced by Weed Management Options

growth period of 2-8 weeks (Tewari et al., 1989) was observed especially in these treatments leading to enhanced photosynthetic activity and partitioning of assimilates, resulting in improved yield attributes and yield. The sowing of pigeonpea crop for every two lines of groundnut helped to remove the prevailing weeds in those lines and slow growth of the pigeonpea facilitated the good growth of the groundnut.

The lowest values of the yield attributes (number of mature pods per plant), pod yield, haulm yield were registered with the unweeded control $\left(T_{10}\right)$. This might be due to the shorter plant height, lower number of branches and lower dry matter per plant owing the competition faced by the crop for moisture, light, nutrients and $\mathrm{CO}_{2}$ due to the uncontrolled weeds. The results of the present investigation strongly support the findings of Reddy and Reddy (2004), Kushwah and Vyas (2005), Dutta et al. (2005), Madhavi et al. (2008), Kalhapure et al. (2013), Yadav et al. (2014), Dixit et al. (2016), Haque et al. (2016) and Vora et al. (2019).

\section{Pigeonpea}

\section{Number of pods per plant}

Significantly higher number of pods per plant (223.2, 201.5 and 212.3 in 2019-20, 2020-21 and pooled results, respectively) in pigeonpea was recorded with the weed free treatment $\left(T_{9}\right)$ and it was statistically equivalent to $\mathrm{IC}+\mathrm{HW}$ at 15 DAS $\mathrm{fb}$ sodium-acifluorfen $16.5 \%$ + clodinafoppropargyl $8 \%$ (Premix) $1 \mathrm{~kg} \mathrm{ha}^{-1}$ at 45 DAS as PoE $\left(\mathrm{T}_{3}\right)$ and pendimethalin $0.9 \mathrm{~kg} \mathrm{ha}^{-1}$ as PE fb sodium-acifluorfen $16.5 \%$ + clodinafop-propargyl $8 \%$ (Premix) $1 \mathrm{~kg} \mathrm{ha}^{-1}$ at 45 DAS as $\operatorname{PoE}\left(\mathrm{T}_{6}\right)$ in both the years along with pooled results. During 2019-20, the weed free treatment $\left(T_{9}\right)$ was also statistically at par with pendimethalin $0.9 \mathrm{~kg} \mathrm{ha}^{-1} \mathrm{PE} \mathrm{fb} \mathrm{IC}+\mathrm{HW}$ at 45 DAS $\left(T_{1}\right)$. Treatments $T_{3}$ and $T_{6}$ were statistically at par with pendimethalin $0.9 \mathrm{~kg} \mathrm{ha}^{-1} \mathrm{PE} \mathrm{fb} \mathrm{IC}+\mathrm{HW}$ at $45 \mathrm{DAS}\left(\mathrm{T}_{1}\right)$ and pendimethalin $0.45 \mathrm{~kg} \mathrm{ha}^{-1}+$ oxyfluorfen $0.09 \mathrm{~kg} \mathrm{ha}^{-1}$ as $\mathrm{PE}$ fb IC+HW at 45 DAS $\left(\mathrm{T}_{2}\right)$ during 2019-20, 2020-21 and pooled results. Significantly lower number of pods per plant was recorded with the unweeded control (111.2, 81.5 and 96.3 in 2019-20, 2020-21 and pooled results, respectively) during 2019-20, 2020-21 along with pooled results.

\section{Seed yield}

The weed free treatment $\left(T_{9}\right)$ registered significantly higher seed yield (2023, 1861 and $1942 \mathrm{~kg} \mathrm{ha}^{-1}$ in 2019-20, 202021 and pooled results, respectively), which was observed to be statistically on par with $\mathrm{IC}+\mathrm{HW}$ at 15 DAS fb sodiumacifluorfen $16.5 \%$ + clodinafop-propargyl $8 \%$ (Premix) $1 \mathrm{~kg}$ $\mathrm{ha}^{-1}$ at 45 DAS as PoE $\left(\mathrm{T}_{3}\right)$, pendimethalin $0.9 \mathrm{~kg} \mathrm{ha}^{-1}$ as PE fb sodium-acifluorfen $16.5 \%$ + clodinafop-propargyl $8 \%$ (Premix) $1 \mathrm{~kg} \mathrm{ha}^{-1}$ at $45 \mathrm{DAS}$ as $\mathrm{PoE}\left(\mathrm{T}_{6}\right)$ and pendimethalin $0.9 \mathrm{~kg} \mathrm{ha}^{-1}$ as PE fb IC+HW at 45 DAS $\left(T_{1}\right)$ during the first year, while in the second year and pooled data, it was statistically at par with $T_{3}$ and $T_{6}$. However, $T_{1}$ was statistically on par with second best treatment, $T_{3}$ during 2020-21 and pooled results. On the other hand, the unweeded control
$\left(T_{10}\right)$ recorded significantly lowest seed yield (522, 423 and $472 \mathrm{~kg} \mathrm{ha}^{-1}$ in 2019-20, 2020-21 and pooled results, respectively).

\section{Stalk yield}

The weed free treatment $\left(T_{9}\right)$ registered significantly higher stalk yield (3549, 3080 and $3314 \mathrm{~kg} \mathrm{ha}^{-1}$ in 2019-20, 202021 and pooled results, respectively) and was at par with $\mathrm{IC}+\mathrm{HW}$ at $15 \mathrm{DAS}$ fb sodium-acifluorfen $16.5 \%$ + clodinafoppropargyl 8\% (Premix) $1 \mathrm{~kg} \mathrm{ha}^{-1}$ at $45 \mathrm{DAS}$ as PoE $\left(\mathrm{T}_{3}\right)$, pendimethalin $0.9 \mathrm{~kg} \mathrm{ha}^{-1}$ as PE fb sodium-acifluorfen $16.5 \%$ + clodinafop-propargyl $8 \%$ (Premix) $1 \mathrm{~kg} \mathrm{ha}^{-1}$ at 45 DAS as PoE $\left(T_{6}\right)$ during 2019-20, 2020-21 and pooled data. Pendimethalin $0.9 \mathrm{~kg} \mathrm{ha}^{-1}$ as PE $\mathrm{fb} \mathrm{IC}+\mathrm{HW}$ at $45 \mathrm{DAS}\left(\mathrm{T}_{1}\right)$ and pendimethalin $0.45 \mathrm{~kg} \mathrm{ha}^{-1}+$ oxyfluorfen $0.09 \mathrm{~kg} \mathrm{ha}^{-1}$ as PE $f b \mathrm{IC}+\mathrm{HW}$ at $45 \mathrm{DAS}\left(\mathrm{T}_{2}\right)$ were found to be statistically at par with $T_{3}$ and $T_{6}$ during 2019-20 and 2020-21. The unweeded control $\left(T_{10}\right)$ recorded significantly the lowest stalk yield (1201, 1027 and $1114 \mathrm{~kg} \mathrm{ha}^{-1}$ in 2019-20, 2020-21 and pooled results, respectively).

The crop under weed free conditions attained optimum growth possibly due to elimination of weeds from inter and intra rows besides better aeration due to manipulation of surface soil and thus, more space, moisture, light and nutrients were available for the better growth and development, which resulted into superior yield attributes and consequently the highest seed and stalk yields. Among the herbicidal treatments, application of pendimethalin as pre-emergence curbed the establishment of initial flush of weeds and initial interculturealong with hand weeding at 15 DAS removed all the established weed flora and maintained a clean environment around the crop. Application of the ready-mix herbicides at 45 DAS helped to control the mixed weed flora providing a competitive advantage to the crop. The sowing of pigeonpea crop in between the rows of groundnut also helped in removal of the weeds and the groundnut crop acted as a mulch for pigeonpea crop in the later stages curbing the weed growth.

Significantly the lowest values of the yield attributes pod yield, haulm were recorded with the unweeded control $\left(T_{10}\right)$. The severe competition due to unrestricted growth of weeds in this treatment might have inhibited the growth of the crop leading to the inhibited yield attributes, seed and stalk yields. Similar findings were obtained by Srivastava et al. (2004), Singh (2007), Shete et al. (2009), Murali et al. (2013), Goud and Patil (2014), Malik and Yadav (2014), Harithavardhini et al. (2016), Kathirvelan (2017) and Sai and Tigga (2018).

\section{Groundnut pod equivalent yield}

The data on groundnut pod equivalent yield are presented in Table 3 . The weed free treatment $\left(T_{9}\right)$ was significantly superior in groundnut equivalent pod yield 4261, 3856 and $4058 \mathrm{~kg} \mathrm{ha}^{-1}$ in 2019-20, 2020-21 and pooled results, respectively) during both the years as well as pooled results. It was found to be statistically at par with $\mathrm{IC}+\mathrm{HW}$ at $15 \mathrm{DAS}$ fb sodium-acifluorfen $16.5 \%$ + clodinafop-propargyl $8 \%$ 
Productivity of Groundnut + Pigeonpea Relay Intercropping System as Influenced by Weed Management Options

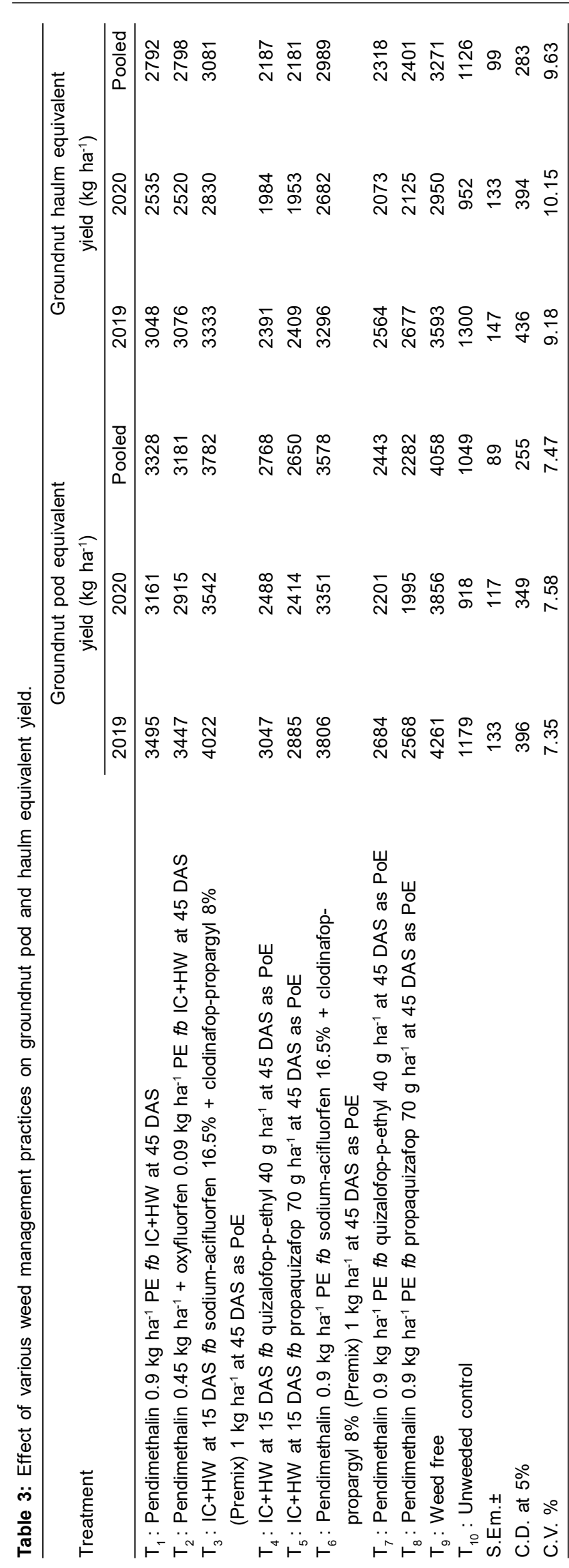

(Premix) $1 \mathrm{~kg} \mathrm{ha}^{-1}$ at $45 \mathrm{DAS}$ as $\operatorname{PoE}\left(\mathrm{T}_{3}\right)$ and further, this treatment $\left(\mathrm{T}_{3}\right)$ was statistically equivalent to pendimethalin $0.9 \mathrm{~kg} \mathrm{ha}^{-1}$ as PE fb sodium-acifluorfen $16.5 \%$ + clodinafoppropargyl $8 \%$ (Premix) $1 \mathrm{~kg} \mathrm{ha}^{-1}$ at $45 \mathrm{DAS}$ as PoE $\left(\mathrm{T}_{6}\right)$ in 2019-20, 2020-21. In pooled data, the weed free treatment $\left(T_{9}\right)$ was significantly superior over all other treatments and $T_{3}$ and $T_{6}$ were at par with each other which were found to be the next best treatments. The unweeded control $\left(T_{10}\right)$ due to heavy weed competition recorded significantly the lowest groundnut pod equivalent yield (1179, 918 and $1049 \mathrm{~kg} \mathrm{ha}^{-1}$ during 2019-20, 2020-21 and pooled results, respectively).

\section{Groundnut haulm equivalent yield}

Significantly higher groundnut haulm equivalent yield (3593, 2950 and $3271 \mathrm{~kg} \mathrm{ha}^{-1}$ in 2019-20, 2020-21 and pooled results, respectively) was recorded with the weed free treatment $\left(\mathrm{T}_{9}\right)$ during both the years as well as pooled results. $\mathrm{IC}+\mathrm{HW}$ at 15 DAS fb sodium-acifluorfen $16.5 \%$ + clodinafoppropargyl $8 \%$ (Premix) $1 \mathrm{~kg} \mathrm{ha}^{-1}$ at 45 DAS as PoE $\left(\mathrm{T}_{3}\right)$ and pendimethalin $0.9 \mathrm{~kg} \mathrm{ha}^{-1}$ as PE fb sodium-acifluorfen $16.5 \%$ + clodinafop-propargyl $8 \%$ (Premix) $1 \mathrm{~kg} \mathrm{ha}^{-1}$ at 45 DAS as PoE $\left(T_{6}\right)$ were statistically equivalent with each other and also with $\mathrm{T}_{9}$ (Weed free) during 2019-20, 2020-21 and pooled data. Pendimethalin $0.9 \mathrm{~kg} \mathrm{ha}^{-1}$ as PE $\mathrm{fb} \mathrm{IC}+\mathrm{HW}$ at 45 DAS $\left(T_{1}\right)$ and pendimethalin $0.45 \mathrm{~kg} \mathrm{ha}^{-1}+$ oxyfluorfen $0.09 \mathrm{~kg}$ $\mathrm{ha}^{-1}$ as PE $\mathrm{fb} \mathrm{IC}+\mathrm{HW}$ at 45 DAS $\left(\mathrm{T}_{2}\right)$ were recorded to be statistically at par with $\mathrm{T}_{6}, \mathrm{~T}_{3}$ in the three cases. The unweeded control $\left(T_{10}\right)$ due to heavy weed competition recorded significantly the lowest groundnut haulm equivalent yield (1300, 952 and $1126 \mathrm{~kg} \mathrm{ha}^{-1}$ in 2019-20, 2020-21 and pooled results, respectively).

Under weed free conditions, both the crops might have had a luxuriant growth supplementing each other by their nitrogen fixing capacity and hence, ultimately resulting in superior yield of both crops and also groundnut equivalent yield. In weed management treatments, it might be due to timely and effective control of weeds right from germination of crops by intercultivation coupled with post-emergence herbicides which provided weed free environment to the groundnut and pigeonpea resulted in higher yields than other treatments (Bhagyashree et al., 2018). The sowing of the pigeonpea in between the lines of groundnut after a month had mulching effect along with removing the weeds in those lines. The results of this study confirmed the earlier findings of Tomar et al. (2004), Singh et al. (2005), Pardeshi et al. (2008), Kumawat (2013) and Khazi et al. (2018).

\section{CONCLUSION}

On the basis of the results obtained from the two-year field investigation, it could be concluded that higher yield along with effective weed management in kharif groundnut + pigeonpea relay intercropping under South Saurashtra Agroclimatic Zone can be achieved by IC+HW at 15 DAS followed by sodium-acifluorfen $16.5 \%$ + clodinafop-propargyl $8 \%$ (Premix) $1 \mathrm{~kg} \mathrm{ha}^{-1}$ at 45 DAS without any phytotoxic effect on both the crops.

Conflict of interest: None. 
Productivity of Groundnut + Pigeonpea Relay Intercropping System as Influenced by Weed Management Options

\section{REFERENCES}

AICRP (2002-07). All India Coordinated Research Project on Crop Science. Available on http://www.icar.org.in/files/aicrpreport2002-07/AICRPsCropScience.pdf access on dated $26^{\text {th }}$ October, 2014, pp. 129.

Bhagyashree, Ananda, N., Chittapur, B.M., Umesh, M.R. and Veeresh, H. (2018). Bioefficacy of herbicides in groundnut (Arachis hypogaea L.) + pigeonpea [Cajanus cajan (L.) Millsp.] (4:1) intercropping system. International Journal of Chemical Studies. 6(4): 2645-2650.

Dixit, J.P., Kasana, B.S. and Singh, Y.K. (2016). Effect of pre and post emergence herbicides on pod yield and economics of groundnut (Arachis hypogaea). International Journal of Farm Science. 6(1): 90-95.

Dutta, D., Bandyopadhyay, P. and Banerjee, P. (2005). Integrated weed management in rainfed groundnut (Arachis hypogaea) in acid lateritic soils of West Bengal. Journal of Crop and Weed. 2(1): 47-51.

Goud, V.V. and Patil, A.N. (2014). Increase in growth and yield of pigeonpea with weed management. Indian Journal of Weed Science. 46(4): 389-391.

Haque, M., Acharya, S.S., Roy, A.C., Gupta, S.K. and Ghosh, M. (2016). Competitive ability of intercrops and herbicides for controlling weeds in maize (Zea mays L.). Advance Research Journal of Crop Improvement. 7(1): 161-170.

Harithavardhini, J., Jayalalitha, K.; Rani, Y. A. and Krishnaveni, B. (2016). Efficacy of post emergence herbicides on weed control efficiency, partitioning of dry matter and yield of blackgram [Vigna mungo (L.) Hepper]. International Journal of Food, Agriculture and Veterinary Sciences. 6(2): 39-44.

Kalhapure, A.H., Shete, B.T. and Bodake, P.S. (2014). Integration of chemical and cultural methods for weed management in groundnut. Indian Journal of Weed Science. 46(3): 264-266.

Kathirvelan, P. (2017). Influence of weed management on weed dynamics and yield of machine sown pigeonpea [Cajanus cajan (L.) Millsp.] under dryland conditions. International Journal of Current Microbiology and Applied Sciences. 6(11): 3237-3245.

Khazi, G.S., Karle, A.S., Asewar, B.V., Patil, V.D. and Tamboli, N.M. (2018). Effect of integrated weed management practices on yield and weed dynamics in soybean + pigeonpea intercropping system. International Journal of Pure and Applied Bioscience. 6(Sp.1): 128-135.

Kumawat, N., Singh, R.P., Kumar, R. and Om, H. (2013). Integrated weed management in kharif groundnut (Arachis hypogaea L.). M.Sc. thesis (Unpublished), Mahatma Phule Krishi Vidhyapeeth, Kolhapure, Maharashtra.

Kushwah, S.S. and Vyas, M.D. (2005). Efficacy of herbicides against weeds in rainfed groundnut under Vidhyan plateau of Madhya Pradesh. Indian Journal of Weed Science. 38(1 and 2): 62-64.

Madhavi, M., Rao, S.S. and Reddy, C.R. (2008). Integrated approach for weed control in Rabi groundnut (Arachis hypogaea L.). Journal of Research-ANGRAU. 39(1): 6063.
Malik, R.S. and Yadav, A. (2014). Effect of sowing time and weed management on performance of pigeonpea [Cajanus cajan (L.) Millsp.]. Indian Journal of Weed Science. 46(2): 132-134.

Murali, K., Mallesha and Fakeerappa, A. (2013). Effect of integrated weed management practices on growth, yield and weed dry weight of pigeonpea. Ecology Environment and Conservation. 19(4): 1279-1283.

Pardeshi, S.S, Paturde, J.T., Kagne, S.V., Chavan, P.G., Dhale, S.A. and Raut, V.S. (2008). Effect of weed management practices on weed growth and grain yield of maize + pigeonpea intercropping system. Journal of Soils and Crops. 18(2): 454-457.

Reddy, B.R. and Reddy, P.M. (2004). Effect of weed management and staggered sowing of sunflower on weed dynamics and groundnut pod equivalent yield of groundnut and sunflower intercropping. Indian Journal of Weed Science. 38(1 and 2): 213-217.

Sai, N.K. and Tigga, R. (2018). Effect of sowing date and weed management techniques on yield attributes and yield of blackgram (Vigna mungo L.). International Journal of Chemical Studies. 6(6): 2705-2708.

Sathyapriya, R., Chinnusamy, C., Murali, P. A., Janaki, P. and Babu, C. (2013). Evaluation of oxyfluorfen (23.5\% EC) herbicide on weed control, economics and profitability of groundnut in the western zone of Tamil Nadu. Chemical Science Review and Letters. 6(21): 88-93.

Shete, B.T., Dhage, V., Patil, J.B. and Barve, U.V. (2009). Effect of integrated weed management in pearl millet-pigeonpea intercropping. Annals of Plant Physiology. 23(1): 66-68.

Singh, B. D., Prakash, O. and Varshney, G. (2005). Purple nutsedge (Cyperus rotundus L.) management for sustained productivity. Indian Farmers Digest. Dec-2005: 17-20.

Singh, R.S. (2007). Integrated weed management in pigeonpea (Cajanus cajan). Environment and Ecology. 25(Sp.3A): 780-782.

Singh, B.C. (2020). Grand challenges in weed management. Frontiers in Agronomy. 1: 2673-3218.

Srivastava, G.P. and Srivastava, V.C. (2004). Chemical weed control in pigeon pea (Cajanus cajan) + soybean (Glycine max) intercropping system. Journal of Research, Birsa Agricultural University. 16(1): 91-94.

Tewari, A.N., Singh, K.K., Sharma, J.K. and Tewari, U.S. (1989). Crop weed competition in groundnut+pigeon pea intercropping under rainfed conditions. Indian Journal of Agronomy. 34: 167-171.

Tomar, J., Singh, H.B., Vivek and Tripathi, S.S. (2004). Integrated weed management in intercropping of mungbean (Vigna radiata) and cowpea fodder (Vigna unguiculata) with pigeonpea (Cajanus cajan) under western U. P. Condition. Indian Journal of Weed Science. 36(1 and 2): 133-134.

Vora, V.D., Parmar, A.D., Hirpara, D.S., Kanzaria, K.K., Desai, N.R., Kaneria, S.C. and Modhavadiya, V.L. (2019). Weed Management in kharif groundnut. International Journal of Current Microbiology and Applied Sciences. 8(11): 429-434.

Yadav, J.P., Banga, R.S., Yadav, A., Sheoran, P. and Bajiya, R. (2014). Efficacy of herbicides integrated with manual weeding in groundnut. Environment and Ecology. 32(2): 554-557. 